Est Ag 37 (2002) 549-574

\title{
La amistad en Epicuro
}

\section{Introducción}

La teoría de la amistad ${ }^{1}$ se puede considerar como la parte central de la teoría epicúrea sobre la vida social. La amistad era la alternativa o respuesta que daban a la vida de la sociedad y el mundo que les rodeaba. Frente a la ciudad-estado, proponían una vida comunitaria basada en lazos de amistad. El término griego $\phi \imath \lambda \hat{i} \alpha$ significa tanto amor como amistad y Epicuro, aunque sigue la tradición anterior y considera la amistad como una virtud ( $S V^{2} 23$ ), presenta una característica de profunda originalidad: para él es esencialmente un sentimiento, un afecto y una profunda entrega hacia la persona ${ }^{3}$.

Epicuro, históricamente, es heredero de dos tradiciones bien diferenciadas pero complementarias a la vez: por un lado, del materialismo de Demócrito y, por otro, del humanismo socrático y los posibles contactos con la Academia y el Liceo. Este doble aspecto de sus escritos se deja ver de manera especial en el tema de la amistad y, como consecuencia de esa doble influencia, algunas de sus posiciones pueden parecer contradictorias ${ }^{4}$. Por una parte la amistad - al igual que toda su teoría social- se funda en la utilidad, en su carácter pragmático -" tiene su origen en los beneficios" (SV 23)-; pero, al mismo tiempo, lo más característico de la amistad es su sentido o ideal altruista. La amistad epicúrea es un fin en sí misma -"la amistad es deseable por sí mima" ( $S V$ 23)-, sin pensar en el provecho que se puede obtener de ella. Una explicación de esta disparidad pudiera ser esta: al comienzo, por

1 MüLLER, R., Die Epikureische Gesellschaftstheorie (=SGKA(B) 5), Akademie Verlag, Berlin 1972, p. 112 y 116.

2 EPICURO, Sentencias Vaticanas.

3 PESCE, D., Saggio su Epicuro. Seconda edizione aumentata, Paideia Editrice, Brescia 1988 , p. 126.

${ }^{4}$ FRAISSE, J.C., Philia, La notion d'amitié dans la philosophie antique. Essai sur un problème perdı et retrouvé (Bibliothèque d'histoire de la Philosophie), Librairie Philosophique J. Vrin, Paris 1984, p. 289. 
influencia de Demócrito, tiene unos planteamientos más utilitaristas, mientras que después, debido a la influencia aristotélica-platónica, se va abriendo hacia posiciones más desinteresadas o humanitarias.

Antes de estudiar la amistad veamos los distintos tipos de amor y cómo cabe situar la amistad dentro de ellos.

\section{El amor y la amistad}

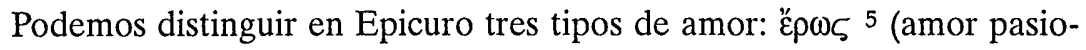
nal), $\phi \imath \lambda i \alpha$ (amor no pasional o afectivo) y $\tau \dot{\alpha}$ A $\phi \rho o \delta i \sigma i \alpha$ (amor sexual o simple relación sexual). De estos tres tipos, del único que hace elogios y habla de un modo laudatorio es el amor $\phi \imath \lambda i ́ \alpha$, como más adelante detallaremos. El ¿ $p \omega \zeta$ siempre es desaconsejado y criticado por Epicuro. Respecto del amor sexual y del matrimonio, mantiene una posición contradictoria, a juzgar por los textos, fragmentarios, que conservamos.

Siguiendo su clasificación de los deseos (KD 29 y 30), Epicuro desaprueba el amor-pasión 7 , pues es resultado de una vana ilusión y su existencia va asociada a todo tipo de turbaciones y zozobras que impiden la sereni-

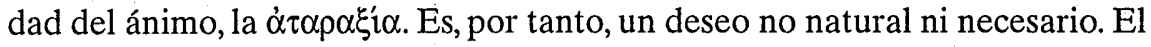
amor-sexual, que responde a las necesidades elementales de la naturaleza y debe ser satisfecho, es un deseo natural, pero no necesario ${ }^{8}$. Satisfacer este deseo es un modo de descargar tensiones y paliar los deseos de la carne; es importante que este deseo no se convierta en pasión, pues produciría la angustia y la turbación. Por último, el amor de amistad correspondería a los deseos naturales y necesarios 9 , que, si no son satisfechos, producen dolor, resultando que no vale la pena vivir la vida.

5 FlACELIÈre, R., Les épicuriens et l'amour, en Revue des Etudes Grècques 67 (1954) 69-70. Reconoce que en los fragmentos que conservamos de Epicuro es más frecuente la

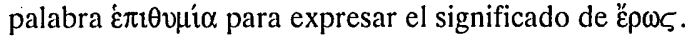

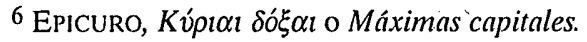

7 Us. 483. Cf. FlACELIÈRE, R., Les épicuriens, p. 70. Rist, M. J., Epicurus on Friendship, en $C P 75$ (1980) 126. La pasión es para Epicuro un deseo intenso de sexo, acompañado por un intenso anhelo y angustia. Por lo tanto, es una clase de locura y, obviamente, es dolorosa.

8 García Gual, C.,-Acosta, E., Ética de Epicuro. La génesis de una moral utilitaria (=Rescate Textual 1), Barral, Barcelona 1974, p. 244-245. Epicuro no ha considerado negativos los placeres sexuales en sí mismos, sino en la medida en que, relegados a un plano secundario en relación con el placer máximo de la ausencia de dolor y asociados en ocasiones a la disipación, pueden conllevar similares motivos de turbación que el amor-pasión.

${ }^{9}$ Fraisse, J.C., Philia, p. 295. Véase también MITSIs, P., Epicurus' Ethical Theory. The Pleasures of Invulnerability, Cornell University Press, Ithaca, London 1988, p. 127. Epicuro 
Analicemos más a fondo el amor sexual y el amor-pasión en los epicúreos. Tradicionalmente se ha pensado que Epicuro mantenía una opinión contradictoria. Por una lado, es un deseo natural ( $\left.U s .{ }^{10} 28\right)$, que justifica una opinión favorable. En la mayoría de los textos, sin embargo, tiene un sentido negativo, porque perturba a la persona que se deja arrastrar por tales deseos. En D. L. ${ }^{11} \mathrm{X}, 118$ y $S V 51$ nos dice que la unión sexual o las cosas de Venus no benefician ni traen provecho. Aconseja también no enamorarse. Asimismo en la Epístola a Meneceo 132 incluye los placeres del amor entre aquellos que no proporcionan una vida feliz.

Lucrecio ${ }^{12}$, siguiendo a su maestro en el libro $D R N^{13}$, IV a partir del v. 1037, habla sobre el sentimiento de amor y sus peligros; lo describe como una plaga, una ilusión peligrosa y funesta ${ }^{14}$, como un obstáculo para la ataraxia. Así se expresa en los versos 1073-1076: "Mas no se priva de los frutos de Venus el que evita el amor, antes elige los placeres que están libres de pena. Pues no hay duda que el goce es más puro para el sano que para el aquejado por la pasión". Lucrecio sostiene que es más fácil evitar caer en las redes del amor que huir una vez que se ha caído.

La solución de Lucrecio para escapar a las turbaciones de la pasión amorosa consistiría en favorecer la promiscuidad, no atarse a ninguna mujer en particular y, así, no sentirse agobiado sin límites. Los versos 1064-1067 aconsejan "evitar lo que da pábulo al amor y volver la mente a otras ideas: des-

considera que no se puede ser feliz sin amigos. La amistad es un deseo necesario; sin embargo, se presenta el problema de incluir el deseo de un bien externo como la amistad entre lo necesario para la felicidad y, de este modo, dejamos al sabio vulnerable ante lo imprevisto y la frustración.

10 Usener, H. (ed.), Epicurea (=Studia Philologica 3), L'Erma di Bretschneider, Roma 1963, lxxx-446 pp.

11 DióGenes LaERCIO

12 StEARNS, B. J., Epicurus and Lucretius on Love, en CJ 31 (1936) 347-351. Este estudio de 1936 considera que las opiniones de Epicuro y Lucrecio son contrarias. Epicuro probablemente no se opuso al amor y al matrimonio, ya que no menciona nada en sus Máximas Capitales y sólo aparecen estas ideas en cartas individuales. Stearns defiende que Epicuro favoreció el amor y el matrimonio en general, pues no concibe la vida buena sin el placer del amor y él tuvo una actitud favorable hacia sus padres y miembros de su familia. Por otra parte, sus discípulos favoritos estaban casados y él mismo mostró sentimientos de amor hacia los niños. Lucrecio, al contrario, se opuso al amor y al matrimonio, tal vez por sus experiencias personales negativas. Stearns concluye diciendo que Lucrecio, por lo tanto, no siempre siguió a su maestro y que la doctrina epicúrea no fue tan estática.

13 LUCRECIO, De la Naturaleza.

14 KLEVE, M. K., Lucrèce, l'épicurisme et l'amour, en Actes du VIII Congrés AGB,p. 376. Este ataque tan vehemente del poeta se ha interpretado como consecuencia de su propia experiencia negativa. 
cargar el humor acumulado contra un cuerpo cualquiera, antes que tenerlo y guardarlo para un único amor, y procurarse así cuitas e inevitable dolor". En este sentido Lucrecio distingue dos modos de vivir el amor: el de los apasionados, quienes se entregan por completo a una mujer y viven preocupados, y el de los no apasionados, quienes aseguran su independencia e imperturbabilidad con la promiscuidad. Según Bailey, Lucrecio sería mucho más categórico que Epicuro en la reprobación del amor-pasión, pero mucho más moderado que su maestro en aceptar el acto sexual como satisfacción de un deseo natural. La concepción de Epicuro es más ascética ${ }^{15}$.

A García Gual-Acosta ${ }^{16}$ les parece interesante y sugerente la propuesta de Kleve, quien considera que Epicuro, igual que Lucrecio, podría haber estimado como un bien el amor sexual de los desapasionados y promiscuos y rechazado como pernicioso el amor sexual de los que se entregan a una mujer en exclusiva. Con esta interpretación, desaparece la contradicción de Epicuro relativa al amor sexual y al amor-pasión. Epicuro rechazaría el amor-pasión y las relaciones sexuales que se refieran a una persona concreta, y, por lo tanto, el matrimonio. Por otra parte, el maestro no se opondría a las relaciones sexuales que son naturales; pero siempre habría que evitar caer en la pasión, pues termina por esclavizar. Esto es así porque para los epicúreos lo más preciado era conseguir la $\alpha \tau \alpha \rho \alpha \xi i \alpha$, un estado libre de dolor y turbación, un placer catastemático: En cambio, el placer sexual es cinético y la pasión a que da origen puede perturbar la calma, razón por la que el sexo puede ser problemático para un epicúreo. Tanto para Epicuro como para Lucrecio el sexo es un placer natural pero nada más.

Aceptando esta interpretación, Epicuro en D. L. X, 117-118 tendría una actitud negativa respecto a las relaciones sexuales y al matrimonio, en contradicción con su actitud vital respecto a la mayoría de sus amigos que estaban casados o respecto de su familia, como nos recuerda Stearns y el texto D. L. X, 119: "el sabio puede incluso casarse y tener hijos, según las circunstancias de la vida". El texto es, sin duda, problemático 17 pues, siguiendo a Gassendi, algunos críticos lo han tergiversado, ofreciendo una traducción de la que resulta lo contrario, esto es, que el sabio ni se casará ni tendrá hijos.

15. KLEVE, M. K., Lucrèce, p. 377 y 380.

16 García Gual, C.,- Acosta, E., Etica, p. 243-244.

17 Chilton, C. W., Did Epicurus approve of Marriage? A study of Diogenes Laertius $X$, 119, en Phronesis 5 (1960), p. 71-74; GriLl, A., Epicuro e il Matrimonio (D. L. X,119), en $R C S F 26$ (1971) 51-56. Este último admite las influencias de Demócrito contrarias al matrimonio; expone los testimonios de Clemente de Alejandría, Séneca, Plutarco (Us. 555) y Epicteto (Ench. 3,7,19) en contra del matrimonio. Viene a decir que Epicuro lo entiende en circunstancias especiales de la vida. 
Desde luego hay razones para afirmar que Epicuro mantuvo una actitud contraria al matrimonio. El camino hacia la felicidad es, según él, la $\alpha \tau \alpha \rho \alpha \xi i \alpha$, libertad frente a las preocupaciones (Ep. Men. 128), libertad que se consigue restringiendo las necesidades del presente y las esperanzas para el futuro, cuyo fruto es la $\alpha$ $\tau \dot{\alpha} \rho \kappa \varepsilon \imath \alpha(S V 77)$. Otra razón del rechazo de las relaciones familiares es que vienen impuestas, pues normalmente no son elegidas libremente, al contrario que las amistades ${ }^{18}$. Según esto, se entiende que al бoфóc se le recomiende abstenerse de la familia y de las responsabilidades de mantenerla. Él mismo enumera las ventajas del celibato (Us. 525). Epicuro, pues, seguiría a Demócrito en su rechazo del matrimonio ${ }^{19}$. El testimonio de Clemente de Alejandría lo confirma (Us. 526).

De todas maneras no acabo de ver claro cuál es la actitud de Epicuro y los epicúreos en relación con el matrimonio. Hay algunos puntos que no explican suficientemente los que defienden la actitud negativa:

- La mayoría de sus amigos y los miembros de la escuela estaban casados.

- Su cariño hacia los niños al acoger los hijos de sus amigos 20.

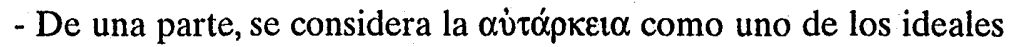
de vida y, de otra, se sostiene que no se puede ser feliz sin la compañía de los amigos (Séneca $E p .9,1$ ).

- Las $S V 61$ y 62 hablan de las relaciones entre padres e hijos.

Se puede concluir diciendo que el problema sigue abierto, pues hay razones para defender ambas posiciones. Hay que constatar que Epicuro no se

${ }^{18} \mathrm{Tal}$ vez para entender la actitud de Epicuro hacia el matrimonio tengamos que pensar la realidad de la época. Entonces sería probablemente un contrato que no implicaba amor (en el sentido contemporáneo), ni una relación amistosa en pie de igualdad entre los cónyuges. Tampoco se concebía una relación entre padres e hijos como la actual. La amistad, e incluso la atención paternalista hacia los más jóvenes, son posibles en la comunidad epicúrea, pero no en la familia. Ésta puede ser más bien fuente de problemas.

19 DEMóCRITO, Los filósofos presocráticos III (=BCG 28), Gredos, Madrid 1980 (DK 68 B 275, 276 y 277), p. 382-383.

20 Erler, M., Philologia medicans. La lettura delle opere di Epicuro nella sua scuola, en Giannantoni, G., e Gigante, M. (ed.), en Epicureismo Greco e Romano, 517-518. Hay una frase que se atribuye a Epicuro contraria a este amor a los infantes: "el amor por los niños no existe por naturaleza"; pero, según la interpretación que se da aquí, es que el amor a los niños no nace de la naturaleza, sino que surge sólo de una libre preferencia. RiST, M. J., Human Value. A Study in Ancient Philosophical Ethics, E. J. Brill, Leiden 1982, p. 142. No tenemos información precisa sobre la opinión de Epicuro sobre los niños y, aunque parece que estaba más inclinado que sus contemporáneos a considerarlos como mini-adultos o adultos en potencia, no tenemos prueba de que les concediera ningún valor ni derechos. 
casó, seguramente por las circunstancias de la vida. Traduzco con Bailey y García Gual (D. L. X, 119): "El hombre sabio se casará y tendrá hijos, como Epicuro dice en los Problemas y en su obra Sobre la Naturaleza. Pero se casará según las circunstancias de su vida". Según esto, la existencia de la familia y por tanto del matrimonio y la paternidad son consideradas como una cosa natural o normal ${ }^{21}$. En este sentido, otro discípulo de Epicuro, Filódemo de

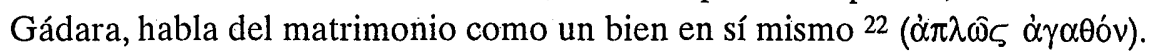

\section{La amistad}

\subsection{La amistad en la tradición griega y la novedad epicúrea}

La palabra $\phi i \lambda i \alpha$ ha sido empleada en la cultura griega desde Homero, Herodoto y Teognis para indicar las relaciones afectivas que surgen entre personas individuales, por ejemplo, entre Aquiles y Patroclo, Diomedes y Ulises, Pílades y Orestes. Pero la amistad como una relación electiva basada en la afección mutua no jugaba un papel formal en los poemas homéricos, y la relación llamada de amistad se dividía en una variedad de vínculos sociales, tales como entre el señor y el vasallo, las relaciones familiares, la hospitalidad, etc. ${ }^{23}$. Los pitagóricos 24 habían insistido sobre la validez e importancia de la amistad en la vida común y para quienes se dedican a la filosofía.

Con Platón este concepto evoluciona y adquiere un sentido social y político. En República 496c 8 y en Ep. VII, 325d razona su retraimiento de la actividad política por la carencia total de amigos y camaradas seguros que le pudieran ayudar a renovar la ciudad-estado. El significado de la amistad y los amigos para Platón es que -como un grupo reducido, pero sano, de hombres-

${ }^{21}$ LONG, A., Pleasure and Social Utility-The Virtues of Being Epicurean, en FLASHAR, H., \& Gigon, O. (ed.), Aspects de la Philosophie Hellenistique, p. 290. A la luz de su optimismo general y del tono filantrópico no tenemos razones para suponer que Epicuro abogaba por el rápido cese de la raza humana.

22 Citado por Kleve, M. K, Lucrèce, p. 382.

23 Fitzgerald, T. J., Friendship in the Greek World Prior to Aristotle, en Fitzgerald, T. J. (ed.), Greco-Roman Perspectives on Friendship, p. 13-34. Aunque Aristóteles es el primero que estudia la amistad de manera sistemática, la práctica de la amistad tiene una historia muy antigua. Según Aristóteles, el modelo de la amistad es en primer lugar "la alegría que las madres sienten al amar a sus hijos" (ENVIII, 9, 1159 a, 27-33), el amor entre marido y mujer, el amor de los padres a los hijos, el amor entre los hermanos, el amor de los amantes, etc. Hablamos de amor de amistad cuando el amor se desarrolla entre humanos; nunca se habla de $\phi i \lambda i ́ \alpha$ con las cosas inanimadas, ni con los animales, ni con Dios.

24 Fraisse, J. C., Philia, p. 59-61. 
forman una comunidad espiritual y ética que puede ser capaz de renovar la sociedad enferma.

Aristóteles ${ }^{25}$ hablará de diferentes clases de amistad ${ }^{26}$, pero continuará con esta identificación de la $\phi \imath \lambda i ́ \alpha \pi 0 \lambda \imath \tau \imath \kappa \dot{n}$ con la concordia dentro de la ciudad 27 y reconocerá que la amistad más elevada o verdadera es la $\phi \imath \lambda i ́ \alpha$ $\tau \varepsilon \lambda \varepsilon i ́ \alpha, o$ amistad de virtud.

Según Konstan ${ }^{28}$, que sigue a Mitsis, hay que distinguir en Epicuro

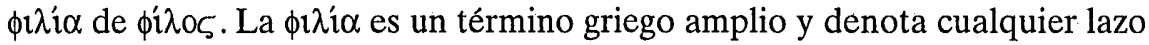
afectivo entre individuos, amigos, parientes o ciudadanos. La amistad en los fragmentos de Epicuro se refiere al amor, simpatía o solidaridad que une a gente en diversas relaciones. El rango semántico de $\phi i \lambda i \alpha$ es mucho más extenso que el del nombre $\Phi^{\prime} \lambda{ }^{\circ} \zeta$, que tiene el mismo significado que amigo en español. $\Phi \mathfrak{i} i \alpha$ puede hacer referencia también a la relación entre los $\phi i ́ \lambda o r$. Epicuro menciona $\phi i ́ \lambda$ or en relación con la utilidad pragmática y la lealtad, mientras que $\phi i \lambda i \alpha$ tiene una cualidad de sentimiento que es durable y está asociada con la felicidad.

25 Fraisse, J.C., Philia, p. 189-286. Es de suponer que Epicuro ha conocido las bases fundamentales de las tesis aristotélicas. Para el Estagirita es en la esfera moral del individuo donde la amistad encuentra su contexto auténtico y en relación con la adquisición de la felicidad donde deben hallarse sus fundamentos. Uno puede alcanzar el sumo bien en sí mismo, sin necesidad de acudir a ninguna ayuda exterior; el sabio es autosuficiente. No obstante, la presencia del otro contribuye a perfeccionar la felicidad por los lazos de amistad (EN 1170 a 5-8). Para Epicuro el hombre encuentra la felicidad en el ámbito de la propia experiencia, el sabio por sí mismo es feliz. Desde el momento que vivimos gozamos ya, por el simple hecho de vivir. Sin embargo, si se quiere persistir en el placer y obtener placeres más puros, es más fácil la mediación del amigo; por eso el sabio, aunque se basta a sí mismo, puede procurarse amigos (Sén. Ep. 9,1).

${ }^{26}$ Aristóteles, Ética Nicomáquea. Ética Eudemia (=BCG 89), In. Emilio Lledó, tr. Julio Pallí Bonet, Gredos 1985, 326-328 pp. (EN VIII, 3, 1156 a $7 \mathrm{ss).} \mathrm{Habla} \mathrm{de} \mathrm{tres} \mathrm{clases} \mathrm{de}$ amistad: la primera basada en la utilidad, para obtener ventajas o beneficios; la segunda fundada en el placer, para conseguir cosas agradables, es decir, la obtención de algún placer, y la tercera apoyada en la virtud, para buscar el bien. Esta tercera clase es la verdadera amistad para Aristóteles, la que busca el bien del amigo por él mismo. La amistad es el deseo del bien en otra persona por sí misma; nos atrae el bien que descubrimos en otro ser no como instrumento útil o como fuente de placer, sino por la persona misma. La amistad de este tipo no se puede encontrar en grupos de muchas personas, sino en un círculo reducido, pues es imposible ser amigo de muchos por la excelencia y por ellos mismos.

27 Recordemos que la amistad en el uso greco-romano tiene un significado político de cohesión social y centrado en la pólis clásica que está ausente en el concepto moderno. EN VIII,1, 1155 a 22: "La amistad mantiene unidas a las ciudades". Política II, 4, 1262 b 5-12: "La amistad es el mayor bien de las ciudades. La unidad de las ciudades es obra de la amistad".

28 Konstan, D., Friendship from Epicurus to Philodemus, en Giannantoni, G., e Gigante, M. (ed.), Epicureismo Greco e Roman, p. 388-389. 394-395. 
Epicuro suprime la vinculación aristotélica de la amistad con la política ( $S V$ 58) y la traspasa al orden de la naturaleza dando al término una acepción universal en el tiempo y en el espacio. Podemos decir con Isnardi-Parente 29 que Epicuro se inclina por dar primacía a la $\phi i \lambda i \alpha$ $\tau \varepsilon \lambda \varepsilon^{i} \alpha$ que ya se encontraba en Aristóteles ${ }^{30}$. Esta 'amistad perfecta' consiste en querer y procurar el bien del amigo por el amigo mismo (EN VIII, 3, 1156 b $10-12$ y 1186 b 1-3) y coincide con la amistad como virtud. En las amistades impulsadas por la utilidad o por el placer se busca lo que el amigo tiene o lo que hace; la $\phi \mathbf{\imath} \lambda \hat{\imath} \alpha$ $\tau \varepsilon \lambda \varepsilon i \alpha$, en cambio, se funda en lo que el amigo 'es'.

La amistad en la filosofía griega se construye siempre sobre el modelo de amor propio y por esta razón será acusada de egoísta y falta de preocupación sincera por otros. Ahora bien, mientras la amistad en Aristóteles está localizada en el contexto de la polis, con el helenismo la amistad se abre a un espacio cosmopolita y tiene un alcance más universal, al mismo tiempo que un sentido más íntimo, por lo que se podrá hablar de amistad altruista, algo que no cabe en Aristóteles, en quien no escapa del amor de sí mismo ${ }^{31}$. Aunque eso no le impida decir que la amistad, elegida por sí misma, consiste más en amar que en ser amado (ENVIII, 1159 a 25-26), lo que podemos llamar amor de benevolencia, o amor generoso, amar a otro por su bien ${ }^{32}$. La explicación de esta aparente contradicción es que el amor a nosotros mismos y el amor generoso a los demás -en la vida de las personas ordinarias- se mezclan, se dan unidos y no es fácil de separar ${ }^{33}$. Nadie se comporta de manera total-

29 TUILIER, A., La notion de $\phi \mathfrak{\imath} \lambda \mathrm{i} \alpha$ dans ses rapports avec certains fondements sociaux de l'épicurisme, en Actes du VIII Congrès AGB, p. 329.

30 Fraisse, J. C., Philia, p. 313. Epicuro rechaza toda confusión que a veces presenta Platón entre amistad y el amor, entendiendo aspectos pasionales que Platón ensalza, como la manía y el delirio.

31 Schroeder, M. F., Friendship in Aristotle and some Peripatetic Philosophers, en Fitzgerald, T. J. (ed.), Greco-Roman Perspectives on Friendship, p. 38. Aristóteles presenta el amor a sí mismo como un modelo para la amistad, uno ama a otro como se ama a sí mismo, o lo que es lo mismo, el amor a sí mismo y el amor de la amistad satisfacen las mismas condiciones. Véase también NYGREN, A., Eros y ágape. La noción cristiana del amor y sus transformaciones, Sagitario, Barcelona 1969, p. 179-180. El amor de amistad o de benevolencia en Aristóteles se apoya sobre el amor a sí mismo.

32. EN IV, 1120 a 10-12. Aristóteles, al hablar de la liberalidad o generosidad, dice que es más propio de la virtud hacer el bien que recibirlo; por eso es más propio del hombre generoso dar a quienes debe que recibir de donde no debe.

33 Comte-Sponville, A., Pequeño tratado de las Grandes Virtudes, Espasa Calpe, Madrid 1998, p. 315. "La mayoría de las veces la benevolencia y la codicia se mezclan, y mejor que sea así para todos aquellos que no son santos, es decir, para todos nosotros, ya que esto nos permite buscar nuestro bien haciendo un poco de bien al otro, mezclar egoís- 
mente interesada o totalmente altruista; la mayoría de nuestros amores son una mezcla de interés y de generosidad.

No se puede negar que la amistad en Epicuro tiene un sentido utilitarista, pero, junto a varios estudiosos ${ }^{34}$, consideraré que tiene fundamentalmente un sentido de gratuidad; es un fin en sí misma ( $S V$ 23). La amistad en Epicuro se abre al horizonte universal helenístico y rompe con las barreras de la polis: ésta es la novedad tanto del estoicismo como del epicureísmo ${ }^{35}$.

\subsection{La amistad es esencial para la felicidad}

La amistad era en la cultura griega uno de los grandes bienes. Demócrito afirmaba que "no vale la pena vivir la vida si no se tiene un buen amigo"36. Aristóteles lo corrobora: "es lo más necesario para la vida; sin amigos nadie desearía vivir, aunque poseyera todos los demás bienes" ${ }^{37}$. En éste como en otros puntos Epicuro está influido por el Estagirita. El fin de la vida es la felicidad y entre los medios de que se vale la sabiduría para alcanzar la felicidad en esta vida, el mayor de todos, es el tesoro de la amistad (KD 27 y 28). Epicuro incluye la amistad como ingrediente esencial que conduce a la felicidad y a la bienaventuranza ${ }^{38}$. Lo cual parece contradecir la $S V 33$ que sitúa la felicidad en la satisfacción de las necesidades naturales y necesarias: "no tener hambre, ni sed, ni tener frío". La amistad es el más elevado de los bienes del mundo ${ }^{39}$ o incluso, como dice $S V 78$, la amistad sería un bien inmortal.

El frg. Us. 542 = Séneca Ep. 19,10 dice: "Debes examinar con quienes comes y bebes, antes de conocer qué vas a comer y beber, porque llenarse de carne sin un amigo es vivir la vida del león o del lobo" 40 . Es más importante

mo y altruismo, en pocas palabras, ser el amigo de nuestros amigos (a quienes deseamos el bien) y de nosotros mismos (pues también nos lo deseamos)".

34 Mitsis, P., Epicurus on Friendship and Altruism, en OSAP 5 (1987) 127-153. Bollack, M. J., Les Maximes de l' Amitié, en Actes du VIII Congrés AGB, Paris 1969, p. 221236. Lledó IÑIGo, E., El epicureísmo. Una sabiduría del cuerpo del gozo y de la amistad, Taurus, Madrid 1995. Long, A., Pleasure and social Utility, p. 305-307.

35 TUILIER, M. A., La notion, p. 320-321. Epicuro atribuye a la amistad una acepción universal en todo el sentido del término. El epicureísmo hace de la amistad una noción universal en el tiempo y en el espacio.

36 DEMÓCRITo, Los filósofos presocráticos, III, 385 (DK 68 B 99).

37 ARISTÓTELES, Etica a Nicómaco, 323 (EN VIII, 1155 a 4-6).

38 Mitsis, P., Epicurus, p. 128. Epicuro considera que sin amigos la felicidad del sabio no es completa.

${ }^{39}$ SCHMid, W., Epikur, en KLAusner, T. (ed.), RAC, V, Stutgart 1961, col. 723.

40 "Ante circumspiciendum est, cum quibus edas et bibas, quam quid edas et bibas, nam sine amico visceratio leonis ac lupi vita est". SÉNECA, Epístolas a Lucilio I, p. 175. 
comer acompañado que lo que se come. Por encima de los placeres del comer está la amistad 41; el sentirse acompañado y el poder tener conversaciones filosóficas durante las comidas es más valorado que lo que se come. Nos recuerda el texto de Aristóteles EN VIII, 1170b10-13: lo importante no es comer en el mismo lugar o en la misma mesa, como pueden hacer los animales, sino que el comer juntos implica convivir, participar de preocupaciones e inquietudes comunes. La amistad posibilita que dos personas tengan la suficiente confianza para hablar, escucharse y abrirse el corazón mutuamente, como testimonia Filódemo de Gádara ${ }^{42}\left(L_{i b}{ }^{43} .28\right)$, y también para practicar la exhortación o corrección sincera ( $L i b$. 38). Sin olvidar los beneficios materiales que nos puede traer la amistad, su principal beneficio es un bienestar espiritual que procede de la intimidad y la comunicación sincera entre tọs miembros de la comunidad epicúrea; es decir, se valora más la intimidad que procede de la amistad que los beneficios que se puedan obtener de ella. Por eso, Epicuro recomienda al final de Ep. Men. 135 practicar estas enseñanzas

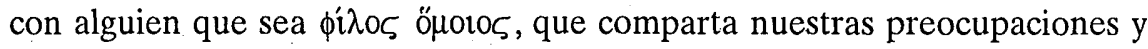
con quien haya sintonía. Recordemos también que la semejanza es una de las características de la amistad para Aristóteles (EN VIII, 1159 b 12-15).

"Este es un amor que desde Epicuro se llama charis, palabra que significa a la vez 'don', 'gratitud', 'alegría', 'hermosura'; que resplandece como la 'flor de la juventud' a la que compara Aristóteles el placer. Pero el bien del amor es: la unión de las almas, que están juntamente en el gozo (placer) y comparten también el dolor. Un amor que, como todo amor, es intrépido y afronta la misma muerte..." 44 .

La amistad puede ir mucho más allá; como aparece al final de la Epístola a Meneceo ${ }^{45}$ adquiere un rango de inmortalidad y, por lo tanto, el que tiene este tesoro vivirá como un hombre entre bienes inmortales. La $S V 78{ }^{46}$ reconoce la importancia de la sabiduría y de la amistad, pero considera esta últi-

41 Fraisse, J. C., Philia, 315. Mitsis, P., Epicurus, p. 123.

42 Philodemus, On Frank Criticism, int. tr. David Konstan, Diskin Clay, Clarence. E. Glad, Johan C. Thom and James Ware, Scholars press, Atlanta 1998, p. $44-45$ y 52-53.

43 Sobre la libertad de palabra

44 Diano, C., Épicure: La philosophie du Plaisir et la société des amis, en EPh 22 (1967) 183. Véase también O'CONNOR, K. D., The Invulnerable Pleasures of Epicurean Friendship, en GRBS 30 (1989) 168.

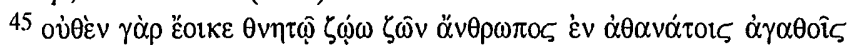

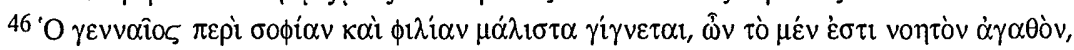
iò $\delta \dot{\varepsilon} \dot{\alpha} \theta \dot{\alpha} v \alpha$ tov. 
ma como un bien inmortal, mientras que la sabiduría sería un bien mortal. Se ha discutido mucho este punto $47 \mathrm{y}$ choca con la tradición griega que entiende siempre la sabiduría 48 como la meta última. Como dice Platón, "sólo Dios

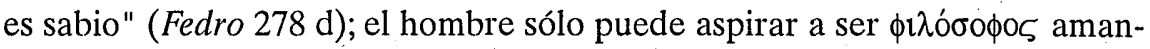
te, buscador de la sabiduría. Para Platón, como se ve en el Fedro y en el Banquete, la amistad, el amor y la sabiduría son al mismo tiempo algo inteligible e inmortal. Otro modo de entender el calificativo de inmortal dado a la amistad consiste en la constatación de que perdura en el recuerdo de los amigos difuntos (Us. 213). La amistad se afirma así como un vínculo más allá de la muerte. La $K D 28$ insiste en la misma idea de que no hay ningún mal eterno; sin embargo esta vida limitada nuestra alcanza la perfección por la amistad. La principal garantía de la seguridad que otorga la amistad es que lleva y demanda una endeble persistencia o continuidad. La amistad viene a ser una resistencia a la muerte, el principio de un placer perpetuo ${ }^{49}$. Para los discípulos de la Academia la amistad y sobre todo el $\varepsilon^{\prime} \omega_{\zeta}$ eran medios o intermediarios para conseguir los bienes superiores: los seres inteligibles, la belleza, el bien, la sabiduría. Para Epicuro y su escuela la amistad es la sabiduría misma; la amistad no es un medio, sino un fin en sí misma 50 ( $S V 23{ }^{51}$ ). Analizaremos

47 BoLLACK, J., Les Maximes, p. 233-235. Bollack junto con Festugière y Bailey defienden que la amistad es inmortal. Schmid, Usener, Diano, Müller consideran que de ese fragmento no se deduce que la amistad sea inmortal y, siguiendo la tradición más genuina griega, consideran que sólo la sabiduría es inmortal... Bollack hace una interesante deducción: $\Sigma o \phi i \alpha$ y $\phi \imath \lambda i \alpha$ forman una unidad que constituyen la verdadera filosofía.

${ }^{48}$ MÜLLER, R., The Epikureische Gesellschaftstheorie, p. 123. La sabiduría es inmortal y la amistad es mortal.

${ }^{49}$ Fraisse, J. C., Philia, p. 302 y 315. La amistad es un bien inmortal pues permite, mucho mejor que la sabiduría, la emancipación del tiempo y satisfacer nuestra vida de alegría hasta la muerte y la misma muerte del amigo. Esta felicidad no es como la de Aristóteles que permite sólo la inmortalización de una elite sino que es accesible a todos. La amistad en los grupos epicúreos abarca a toda humanidad, especialmente a las mujeres y a los esclavos.

50 FestugÈre, J. A., Epicuro y sus dioses, Eudeba, Buenos Aires 1963, p. 24s.

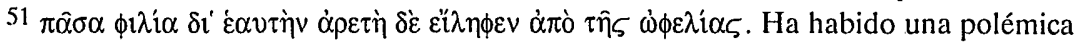

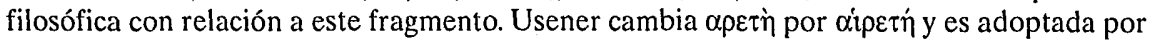
la mayoría de los intérpretes, cambiando el significado. Normalmente se traduce "la amistad es deseable/elegible por sí misma". BollaCk, J., Les Maximes, p. 226. "Toda amistad es un bien (una excelencia, virtud) por ella misma, pero tiene su comienzo en los beneficios". También es posible que Epicuro considerara a la amistad como una virtud; pues ya lo había hecho Aristóteles (EN VIII 1155 a 3). Rodis-LEwIS, G., Épicure et son école (=Idées 342), Gallimard, Saint-Amand 1976, p. 364. Está de acuerdo con Bollack; no hay necesidad de cambiar el manuscrito. RIST, M. J., Epicurus an Introduction, Cambridge University Press, Cambridge 1972, p. 131-133. Considera que sólo el placer tiene un valor último y, por lo tanto, la amistad tiene que estar en función del placer. Tal vez quiera decir que la amistad 
después cómo la idea de utilidad incide en la amistad epicúrea y puede parecer en contradicción 52 con el ideal altruista que defiendo.

La utilidad en relación con la amistad quiere decir que nuestros actos esperan una respuesta en el otro, es decir, que la amistad es algo recíproco y comporta, por lo tanto, un bienestar mutuo. Una respuesta que sea una afirmación solidaria, traducida en beneficio para una de las partes que participan en la relación amistosa. Relación afectuosa, diálogo común, intercambio de pensamientos (Ep. Men. 135): en ese contacto de corazones reside la

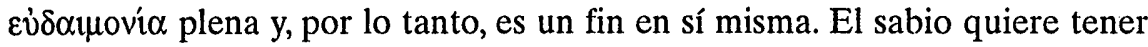
amigos no sólo para que le ayuden en la desgracia o en la necesidad (sentido utilitario), sino para tener a quien amar y por quien sacrificarse (sentido altruista) (Séneca Ep. 9,8-10).

\subsection{La amistad, la sociedad de los amigos y la política}

Los epicúreos consideraban la amistad como el vínculo que creaba la sociedad; pertenecía a la fase de sociedad prepolítica, al periodo anterior al establecimiento de las leyes y la justicia. La amistad era el vínculo de unión entre los hombres, siendo la concordia el fruto de esa amistad; así se la entendía como un sustituto de la justicia o de las leyes. La sociedad de amigos epicúreos -vivían sus relaciones reguladas por la amistad-se presentaba como una alternativa a la sociedad, que necesitaba regular la convivencia con leyes.

Epicuro -en éste como en otros puntos- es deudor de Aristóteles para quien la amistad política 53 está enraizada en la naturaleza y guarda proporción con el grado de inteligencia; es un bien común a todos los hombres de cualquier parte, bien que antecede a la justicia, tanto en el orden del tiempo como de la lógica. Es un principio autónomo de la concordia en la sociedad y se completa a sí mismo. Pero hay una diferencia clara entre Epicuro y Aristóteles. Para este último, la amistad era el punto de apoyo para la vida

conduce al placer sin necesidad de ningún intermediario; pero reconoce que no es muy claro este punto.

52 Bonelli, G., Aporie etiche in Epicuro. Opera stampata con il contributo del Consiglio Nazionale delle Ricerche - Rome (=Latomus 163), Revue D’etudes Latines, Bruxelles 1979, p. 51. La contradicción epicúrea aparece asimismo en la vida moral de la amistad y de la justicia; también aquí intenta superar el utilitarismo, pero siempre tentado en términos de lo útil (interpretando la virtud como placer) y por tanto en términos contradictorios. Por tanto, el intento de superación es contradictorio, lo cual, según Bonelli, sugiere que el mismo Epicuro tuvo conciencia de los límites de su propia doctrina; aunque se da cuenta de la insuficiencia de su hedonismo o utilitarismo, sin embargo, siempre lo defiende.

53 Farrington, B., La rebelión de Epicuro, Laia, Barcelona 1974, p. 50. 
política, un lazo de unión entre la Ética y la Política, entendidas en el contexto de las estructuras sociales. Para los epicúreos, la vida política era la destrucción de la amistad por los aditamentos competitivos que comporta y porque aparecen los deseos vanos e ilimitados. E. Lledó lo ratifica:

"Estos átomos humanos que se unen bajo el impulso de la amistad intentan constituir una estructura política ${ }^{54}$ sin polis, partiendo de otros elementos distintos de esa utilidad armonizadora que distribuía cargas y papeles en las utopías soñadas y descritas por Platón" 55.

Epicuro propone un nuevo tipo de vida social centrado en su grupo de amigos, que no se basa en la lucha por el poder; una sociedad que no destruya la felicidad. Propone un sistema de relaciones humanas que no sea una coraza sino que posibilite la felicidad; por lo tanto, tiene que apoyarse en la filosofía. De todos modos aunque el concepto epicúreo de $\phi \imath \lambda^{i} \alpha$ no tenga la connotación política que tiene el aristotélico, posee el significado de regular las relaciones sociales entre los individuos y carece del sentido íntimo y privado de nuestro tiempo. La amistad en el mundo clásico estaba unida a las relaciones sociales y políticas entre las personas.

En realidad no se puede hablar de derechos humanos en Epicuro, pero la amistad modifica de algún modo esta restricción. Para Epicuro ningún concepto de valor humano intrínseco o de derechos humanos básicos tiene su base en el mundo de la polis, sino en la propia comunidad epicúrea, donde un grupo de aliados se dan unos derechos por acuerdo para todos los que viven allí. Estos derechos se basan en la amistad y tienen unas raíces más profundas que aquellos que se puedan derivar del mero contrato de justicia 56.

En el concepto de amistad epicúreo puede haber una tensión entre el ideal de la $\dot{\alpha} \tau \alpha \rho \alpha \xi i \alpha$ y $\pi 0 \lambda v-\phi \imath \lambda \hat{\imath} \alpha$ (muchos amigos). Filódemo en Sobre la libertad de palabra refleja la presencia de personas de diferente condición social y poder (Lib. col. XXIIb). Los amigos de una comunidad, incluidas mujeres y esclavos, abiertamente confesaban y corregían sus faltas. La amistad entre muchos significaba que los individuos, aunque de diferentes modos de ser y condición social, podían unirse en los grupos de amigos epicúreos. En estos grupos tan heterogéneos y diferenciados tanto en el ámbito social como psicológico la base de la amistad eran las ventajas o beneficios. En cambio, en

54 Rist, M. J., Epicurus on friendship, p. 125. Debemos recordar que la sociedad epicúrea es abiertamente no política, es decir, indiferente a la polis; de aquí que las mujeres y los esclavos no fueran excluidos.

55 LLEDó, E., El epicureísmo, p. 123.

56 Rist, J. M., Human Value, p. 119-1120. 
los grupos en que se puede hablar de semejanza entre los miembros, la amistad se fundamenta en la virtud, en la llamada amistad perfecta de Aristóteles. En el movimiento epicúreo del siglo I a. de C., la base e inicial impulso hacia la amistad son las ventajas o beneficios, pues agrupaba a personas muy heterogéneas. Los epicúreos del tiempo de la República rechazaban la virtud como un requisito ineludible para fundar la amistad. Ellos admitieron sin discriminación una comunidad de amigos individuales, hombres y mujeres, esclavos y hombres libres, de toda clase y condición, y así fundaron una comunidad de amigos que rompía con otras formas reconocidas de límites individuales y grupales. Pero al estar configurados de esta manera, había una predisposición a entender la amistad en el sentido utilitario.

Según Aristóteles, la amistad debía estar basada en la igualdad o semejanza entre los amigos ( $E N$ VIII 8,1159 b 2-4). Por eso tenía que ser exclusiva de pocas personas y restringida a una similitud social y moral entre iguales, que se podría llamar una amistad de carácter aristocrático. En sus grupos de amigos Epicuro rompería con este tipo de amistad clásico abriéndola a una dimensión universalista propia del mundo helenístico; más que restringida a un grupo de personas semejantes, está abierta incluso a las mujeres y a los esclavos. Si no lo podemos afirmar de manera clara por nuestra información limitada sobre Epicuro, sí lo encontramos en la evolución posterior de sus comunidades, como se puede ver en el testimonio de Filódemo de Gádara.

Las dos últimas máximas, $K D 39$ y 40 , hacen referencia a la amistad social 57. El hombre tiene que evitar o eliminar la inseguridad externa que le viene del mundo exterior ( $K D 39$ ); por eso se aparta de aquello que le inquieta o le impacienta. En su vida el hombre precisa de la presencia de los allegados o amigos para obtener el sentimiento de seguridad necesario para afrontar las dificultades cotidianas. La amistad ayuda a eliminar las preocupaciones psíquicas; las $S V 34$ y 61 insisten en que la amistad proporciona seguridad psicológica a la persona en el tiempo presente y de cara al futuro. Lo que realmente nos reconforta cuando somos asistidos por los amigos no es la asistencia misma sino la confianza de su ayuda y el que podemos confiar para el futuro (SV 34). El medio para alcanzar esta seguridad es la amistad; aquellos que han llegado a tener la máxima confianza en sus amigos, quienes han logrado vivir en comunidad familiar de modo agradable, no lloran con gran lamentación la muerte prematura de alguno de ellos (KD 40).

57 Müller, R., Die Epikureische Gesellschafstheorie, p. 117. Tenemos que entender la amistad como algo que ayuda para las relaciones sociales. La amistad es el fundamento o el núcleo esencial que da a los hombres la seguridad que no encuentran en la sociedad o mundo externo; la comunidad de los amigos es como el refugio ante un ambiente hostil. 


\section{La utilidad y el altruismo 58}

La opinión tradicional ha sido pensar que Epicuro tuvo siempre una concepción utilitaria de la amistad, en el sentido de que ésta hace referencia a la identificación de la amistad con el placer ${ }^{59}$. La amistad no puede separarse del placer (Us. 541). La amistad se entiende o tiene sentido en cuanto es beneficiosa para el individuo (SV 23 y D.L. X, 120). Según Cicerón Fin ${ }^{60}$ I, 6668 , los amigos nos proporcionan seguridad y nos liberan del dolor y la frustración y, desde el punto de vista positivo, nos ayudan a adquirir los placeres positivos que surgen de la vida en común. La conclusión es que necesito amigos porque son beneficiosos para mí ${ }^{61}$.

Aunque sea deseable por sí misma, la amistad tiene su origen en necesidades tales como la ayuda, la protección y la seguridad. En otras palabras, los amigos se hacen primero para que la persona obtenga un beneficio directo por la asociación; después se valorará la amistad en sí misma. Por consiguiente, la amistad es tanto un medio para conseguir el fin de la vida -la dicha pla-

58 SaVATER, F., Etica como amor propio, Mondadori, Barcelona 1988, p. 77-90 y $295-$ 312. Reconozco que no es fácil hablar de altruismo en una ética como la epicúrea; la explicación más clara es la de Savater. El altruismo sólo se entiende desde el amor propio; la razón para portarme moralmente respecto a los otros siempre reside en el individuo autointeresado. Si se habla de altruismo es siempre desde el interés propio; no se puede hablar de un altruismo puro. "El sujeto libre no busca en el ejercicio moral nada distinto y posterior a sí mismo, sino seguir mereciendo la confianza y el amor propio racional que se profesa". (pp. 295-296). La moral tiene su raíz en la búsqueda de lo más conveniente para el sujeto; pero este interés propio no se desliga en modo alguno de la comunidad; este amor propio humano no puede no ser social, exige la sociabilidad como condición necesaria para su realización. El amor propio incluye entre sus notas la disposición a la cooperación social, pero, a cambio, toda comunidad tiene como límite irremediable de su proyecto el amor propio de cada uno de sus miembros. En nuestra interpretación, trataremos de ver en los epicúreos algún motivo para amar a los otros, independiente del interés propio.

59 Acosta MÉndez, E., Estudios sobre la moral de Epicuro y el Aristóteles esotérico (=Serie Universitaria 32) Fundación Juan March, Madrid 1977, p. 52-53. La amistad en Epicuro hay que encuadrarla dentro de su teoría ética en la que no identifica la virtud con la felicidad a diferencia de toda la tradición socrática y los estoicos. El punto de partida es la primacía del placer individual en la interioridad moral del individuo. La felicidad consiste en el placer, y la hedoné es la única norma susceptible de ser utilizada como medida de la areté. Las virtudes no se justifican ni pueden ser buscadas por sí mismas, sino por la hedoné a la que conducen. De la misma manera la amistad, que se puede considerar una virtud, no puede buscarse por sí misma; no olvidemos que no se puede dar virtud gratuita (Us. 510). La amistad es uno de los medios para alcanzar la felicidad.

60 Del supremo bien y del supremo mal.

61 Annas, E. J., The Morality of Happiness, Oxford University Press, New YorkOxford 1993, p. 239. 
centera-, un fin en sí misma ${ }^{62}$-la amistad es en sí misma un estado placentero de felicidad ${ }^{63}$-. En esta vida placentera se incluyen las amistades porque nos proporcionan beneficios, pero también porque la preocupación genuina y desinteresada por los otros contribuye a incrementar nuestra felicidad.

Los beneficios que la amistad aporta a los hombres son: protección, ayuda mutua, asistencia, seguridad (KD 13 y 14), confianza en el futuro, ayuda material, consuelo en las dificultades, etc. Todos ellos satisfacen necesidades

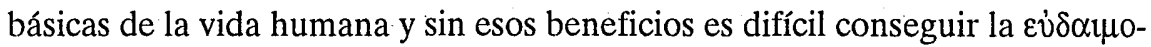
ví $\alpha$. La amistad puede entenderse como el medio para librarse de los miedos y angustias de la vida presente, en el sentido de liberación de los males que angustian al hombre. La amistad surge de la necesidad de lograr ciertas metas, tales como la felicidad o tranquilidad; el origen de la amistad es la asistencia ${ }^{64}$. Los estoicos rechazaron esta visión utilitaria de la amistad y encontraron su origen en la naturaleza (Séneca Ep. 9,17 y Cicerón Amic. 27-28). La virtud, dice Cicerón, es el padre y preservador de la amistad y, sin la virtud, la amistad no puede existir en absoluto (Cic. Amic. 21; cf. 33,100).

La doctrina epicúrea estaba encaminada a disolver los miedos que perturban la serenidad del alma; la presión social del exterior era uno de los obstáculos. La vida feliz no viene de la riqueza, ni de la estima, ni de la opinión vana (Us. 397). La amistad nos proporciona la suficiente tranquilidad de ánimo y el placer suficiente que conduce a la felicidad. Los amigos son una salvaguarda frente a la sociedad extraña y las dificultades de la vida. Lucrecio $(D R N, \mathrm{~V}, 925-987)$ hace una descripción de las personas que viven en la soledad, que favorece este punto de vista. Las personas solitarias actúan por motivos egoístas e inevitablemente se dañan unos a otros.

"Si el placer personal es la última meta de las acciones para los epicúreos, su cálculo hedonista puede incluir a otros sólo como medios para la propia gratificación. En cambio, la amistad altruista requiere, al menos, un interés en los otros por sí mismos" 65 .

Por estas razones siempre ha habido una tendencia a ver a Epicuro como una especie de hobbesian egoist, siempre preocupado o centrado en el interés

62 Annas, E. J., The Morality of Happiness, p. 240. El placer que nosotros buscamos se expande de tal modo que lo alcanzamos precisamente no teniendo preocupación por la acción virtuosa y por el interés de los otros.

63 Long, A., Pleasure and Social Utility, p. 305-306.

64 Rist, M. J., Epicurus on Friendship, p. 123. Para Epicuro la amistad surge para que se puedan obtener beneficios específicos y tangibles.

65 Mitsis, P., Epicurus, p. 99. 
propio. La teoría ética epicúrea se toma comúnmente por ser egoísta porque muchas de sus máximas sobre la amistad expresan una cuidada atención hacia el propio interés. Su énfasis en la seguridad y utilidad proporcionados por los amigos, su esfuerzo continuo por unir la amistad y el placer, su descripción de la amistad como un medio para mitigar la ansiedad, son indicaciones manifiestas de este egoísmo. Si el placer personal es el último fin de las acciones epicúreas, sus cálculos hedonísticos pueden incluir a los otros sólo como un medio para la propia gratificación 66.

Puede que alguna acción parezca desinteresada, pero, si profundizamos un poco, veremos cómo se busca un beneficio. Por ejemplo, lo que es un signo de altruismo, como el dar la propia vida por un amigo (D.L. X, 121b), puede ser una estrategia para evitar el sufrimiento o el dolor, ya que la muerte no es nada para los epicúreos. Incluso textos como el fragmento Us. 540: "No hay nadie que ame a otro si no se quiere a sí mismo" apoyan esta visión. En este fragmento no se discute la existencia del fenómeno social del amor al prójimo, sino que se expresa una opinión decidida sobre su motivación. Esto es puro egoísmo: en la acción de amar al prójimo se está buscando su propio interés ${ }^{67}$. Torcuato piensa que el morir por un amigo es la más clara indicación de un altruismo genuino. Al comienzo de su exposición sobre la amistad epicúrea, Cicerón (Fin. I, 20,65) asocia a Epicuro con las figuras míticas al querer morir por sus amigos: aunque al morir por los amigos pueda quizás dársele una justificación egoísta, también nos hace pensar que esto no se explica totalmente desde el egoísmo, ni se justifica desde el interés personal (Fin. II, 25-26,80-85).

Frente a esta interpretación interesada o utilitaria de la amistad en Epicuro, Cicerón (Fin. I, 20, 65-70 y II, 24-26, 78-85) pone en boca del epicúreo Torcuato tres posiciones distintas de los epicúreos referentes a la amistad y la utilidad. La primera, que correspondería al propio Epicuro (I, 66-68), es la que hemos explicado: la amistad es inseparable del placer y la utilidad, pero reconoce también algún elemento altruista $(I, 66)$ : "no se deben buscar los placeres que atañen a los amigos con la misma intensidad con que buscamos los nuestros... tampoco la amistad puede separarse del placer". El amor que el sabio siente por sus amigos es el mismo que siente hacia sí mismo $(1,67-68)$. Torcuato señala que las amistades abren también la esperanza a un placer en

66. MiTsIs, P., Epicurus on friendship, p. 127-128.

67 MülLER, R., Die Epikureische Ethik (=SGKA(B) 32), Akademie Verlag, Berlin 1991, p. 112. Esta afirmación del fr. 540 Us. nos lleva a uno de los puntos más controvertidos en la interpretación de la teoría de la amistad de Epicuro: la relación entre los motivos egoístas y altruistas. 
el futuro, idea que se corresponde a la $S V$ 34: "no necesitamos tanto de la ayuda de los amigos cuanto de la confianza en esa ayuda", en que realmente nos pueden echar una mano en cualquier momento. Es un sentimiento de solidaridad real, pero no destinado a conseguir beneficios o ventajas inmediatas, sino como remedio para los peligros venideros.

La segunda posición, posterior en el tiempo, cediendo a las críticas de la concepción utilitarista anterior, reconocería la amistad como algo deseable por sí misma (I, 69): "los amigos se llegan a amar por sí mismos incluso sin obtener ventaja de la amistad", aunque nos pueda proporcionar también beneficios. Es una opinión semejante a la que expresa $S V$ 23. Cicerón lo reafirma: "al amigo se le busca primero a causa de la propia utilidad, pero con el trato llega a ser amado como tal y por sí mismo, incluso en la ausencia de cualquier esperanza de placer". (II, 82). Según Torcuato, y se supone que también según Cicerón 68 , esta opinión no es la oficial de la escuela y jamás fue formulada por Epicuro.

La tercera posición (I, 70) estima que la amistad es una clase de pacto, al igual que la justicia, como un contrato para la ayuda mutua.

Podemos decir que Epicuro o los epicúreos se mueven o evolucionan desde una concepción interesada de la amistad hacia una concepción más altruista. Podemos amar a los amigos para obtener beneficios, como confianza y protección en el presente y pensando también en el futuro, y podemos amarlos de una manera más desinteresada. Ambas tradiciones que aparecen en Epicuro, y en sus seguidores representan el epicureísmo genuino. Filódemo de Gádara ( $L i b .28)$ valora la amistad tanto como un medio o valor instrumental -acentúa la seguridad que proviene de ella-, al mismo tiempo que como fin en sí misma ${ }^{69}$.

68 O'CONNOR, K. D., The Invulnerable, p. 177-179. Cicerón en Fin. II, 45-47.60-62. 8285 compara las virtudes con la amistad. Virtudes como la justicia y valentía no se pueden explicar, a veces, en términos de placer. Un soldado, por ejemplo, puede dar la vida por su nación pero no experimenta ningún placer; lo mismo, dice Cicerón, se puede afirmar de la amistad y así la entendía Epicuro.

69 Hay testimonios de la tradición epicúrea -en Filódemo de Gádara-donde no se ve esta contradicción entre la amistad por razones utilitarias y la amistad desinteresada, sino que podemos ver que se dan los dos motivos (cf. Glad, E. C., Frank Speech, Flattery, and Friendship in Philodemus, en Fitzgerald, T. J. (ed), Friendship, Flattery, \& Frankness of Speech, p. 30). Filódemo sugiere que los epicúreos valoran la amistad tanto por sus beneficios como por ser un bien en sí misma. Véase también GLad, E. C., Frank Speech, p. 51. La amistad para Filódemo y Siro correspondería a la segunda clase de Cicerón; señala el placer y la utilidad como el impulso original hacia la amistad, pero después crece la intimidad y el amor y se llega a amar al amigo por sí mismo. 
Pienso que no se puede hablar de una posición única en el epicureísmo sobre su concepción de la amistad. Otra explicación es la que proporciona Cicerón (Fin. II, 25, 80-81): que Epicuro y los epicúreos serían egoístas o buscadores del placer en el plano teórico, pero en la práctica se comportarían de forma desinteresada. Epicuro había sido un hombre de bien y no reguló su vida según el criterio del placer. Dice Cicerón que vivió de tal modo que su vida, orientada por la virtud, desmintió sus palabras, respecto a la búsqueda del placer. Creo que este último testimonio de Cicerón tiene un contenido polémico -trata de dar la razón a los estoicos-, diciéndonos que la virtud es más fuerte que el placer; y por eso, según su testimonio, incluso el mayor enemigo de los estoicos se habría dejado guiar por la virtud en su vida práctica.

De todos modos opino que se pueden encontrar en la teoría de Epicuro algunas argumentaciones para la defensa de la amistad altruista o desinteresada y es lo que intentaré mostrar a continuación.

"La amistad surge por un deseo de placer, pero tanto como va progresando nuestro amor por nuestros amigos crece de tal modo que nosotros les amamos por ellos mismos, incluso sin obtener ventaja de esa amistad. Notemos que los epicúreos no dicen que ningún placer surja de esa amistad, sino ningún beneficio, es decir, ningún beneficio específico. En otras palabras, los epicúreos están pensando en el espíritu de la propia doctrina de Epicuro que hemos relatado más arriba, que la amistad tiene valor por sí misma, pero que ella surge en razón de las ventajas particulares" 70 .

Se pueden reconocer dos momentos de la amistad epicúrea 71 : uno utilitario y otro de ayuda; no son contradictorios, sino que se pueden conjugar. El amor hacia otra persona puede ser un efecto del amor que nos tenemos a nosotros mismos, es decir, tratando de manera altruista a otras personas podemos buscar nuestro propio bien aunque no sea inmediato, por ejemplo, pensando que nos ayudaran en el futuro. De la $S V 39$ extraemos estos dos modos de amar que deben ir unidos: no se puede buscar sólo el provecho en la relación de amistad, pero tampoco rechazarlo, pues va unido a la amistad. Lo que

70 Rist, M. J., Epicurus on Pleasure, p. 124. Torcuato y Rist consideran que algunos epicúreos, sin incluir a Epicuro evolucionan de una amistad interesada a otra más altruista. Yo modestamente creo que podemos aplicar esta idea también a Epicuro.

${ }^{71}$ Long, A., Pleasure and social Utility, p. 305. Señala estos dos momentos de la amistad. La amistad para un epicúreo tiene un valor positivo y una conexión constitutiva con la felicidad, que necesita distinguirse de lo que es la mera justicia. Ningún sentimiento placentero o valor intrínseco incumbe a la conducta justa. Pero la amistad se presenta para ambos como un medio para el placer -por los beneficios y seguridad que provee- y también una parte mayor de vida placentera, un placer en sí misma. 
debemos explicar es cómo puede Epicuro moverse de su premisa egoísta inicial a una afirmación de la amistad altruista. La explicación nos es familiar porque el placer es nuestro único objetivo en la vida y la amistad es un medio especialmente provechoso para alcanzarlo. Condición necesaria para mantener amigos íntimos es que les tratemos como a nosotros mismos; es decir, para alcanzar los máximos beneficios hedonistas de los amigos, debemos tratarlos de modo altruista 72 .

Mitsis ${ }^{73}$ reconoce que no todo se puede reducir al cálculo egoísta de utilidades. Así, por ejemplo se lee en Fin. I, 68: "La amistad del hombre sabio no puede conservarse más que si ama y siente por sus amigos lo que hace y siente por sí mismo". Algo semejante a $S V 23$ y 56 que consideran que el sabio padece más cuando ve sufrir a su amigo que cuando sufre él mismo. Y en $S V$ 39: "Quien sólo busca en la amistad obtener ventajas o beneficios no es un amigo sino un comerciante". Estos pasajes sugieren un fuerte sentido desinteresado en la amistad y se acercan al altruismo. Se enfrentan con la afirmación anterior de que sólo el placer es el fin último de la acción. Más adelante Cicerón (II, 83) argumenta que, si uno ama y trata al amigo como a sí mismo, no lo considera sólo como un medio para su propio placer. Dado que, si ve al amigo como un medio para su propio placer, no cumple el contrato (I, 70), uno debe presentar la amistad como un fin no instrumental y valorar el bienestar del amigo tanto como el suyo propio. La verdadera amistad no se mide por la utilidad, por los beneficios que pueda reportar, sino que se debe medir por el amor que le es propio: debes amar al amigo, no a sus cosas, si quieres tener verdaderos amigos (II, 85). Esto vendría a coincidir con la amistad ver-

72 Mitsis, P., Epicurus on Friendship, p. 140. SAlEM, J., Tel un Dieu parmi les Hommes. L'Etique d'Épicure, Librairie Philosophique J. Vrin, Paris 1994, p. 163-164. Siguiendo a Bailey sugiere que "el altruismo es una forma superior de egoísmo". El vínculo de los principios hedonistas con la amistad desinteresada está asegurado por la sentencia trasmitida por Plutarco (Us. 554: hay más placer en dar que en recibir). Esta concepción altruista de la amistad nos lleva a tratar àl amigo como a nosotros mismos, es decir, amando al amigo nos amamos a nosotros mismos.

73 Mitsis, P., Epicurıs, p. 100-101. Mitsis es el mayor representante de defender el altruismo frente a la tradición hedonista. En cambio Mitsis ha sido cuestionado por O'CONNOR, K. D., The Invulnerable, p. 165-186, quien considera que el ideal de la amistad en Epicuro es hedonista. Epicuro valora a los amigos porque ellos le permiten vivir una vida de calma y tranquilidad. Este ideal excluye los diferentes comportamientos egoístas, pero las razones para esta exclusión no tienen nada que ver con valorar el altruismo como tal. O'Connor frente a las dos alternativas: defender la amistad por razones egoístas o de utilidad y la de defender la amistad por sí misma o altruismo, presenta una tercera vía, un ideal alternativo: valorar la amistad por que da paz y tranquilidad en la vida. El ideal de amistad que presenta Epicuro da más importancia a la camaradería que al altruismo; es decir, a sentirse a gusto con los amigos. 
dadera aristotélica, que consiste en procurar el bien del amigo por lo que el amigo es.

No podemos entender la amistad únicamente como un medio o un instrumento para conseguir el fin de la vida buena que se encuentra en el placer. Las personas al principio se pueden asociar por sentimientos narcisistas, pero poco a poco este amor propio puede ir saliendo hacia los otros y se puede llegar a amar a los amigos incluso sin esperar un beneficio personal. Hay que distinguir entre la utilidad, conseguir ciertas ventajas, y el placer. La asociación en grupos produce ventajas, es indudable, aunque no produzca ningún placer ${ }^{74}$. La amistad puede ser un medio para conseguir la felicidad, pero la amistad además también es y debe ser deseable por ella misma ( $S V 23$ ), es decir, un fin en sí misma. La amistad para un epicúreo tiene un valor positivo y se relaciona con la felicidad. La amistad puede ser tanto un medio para conseguir el placer - por los beneficios y la seguridad que proporciona-como un placer por sí misma, es decir, la amistad puede elegirse por sí misma, a parte de por los beneficios o ventajas que comporta. Esta posición es semejante a la segunda que expresa Cicerón $(I, 69)$ por boca de Torquatus, como hemos visto.

Podemos decir que el comienzo de la amistad son los beneficios, es decir, la utilidad, pero poco a poco va evolucionando este concepto de amistad hasta trascender el ámbito de la utilidad en beneficio de una preocupación desinteresada por el amigo y llegar a amar al amigo por sí mismo ${ }^{75}$ (Fin. II, $26,82)$. Según Bollack este sentido de la amistad se opone al comercio de ella por su realización perfecta, como si fuera una flor que es querida y deseada en sí misma. Epicuro reconoce que podemos valorar algo por su propia razón a parte de su contribución instrumental a nuestra satisfacción, es decir, reconoce en la amistad un valor y un fin diferente del placer, lo cual es inconsistente con las afirmaciones del hedonismo ${ }^{76}$. Pero se puede entender la amistad como algo agradable y deseable, como placer ${ }^{77}$, y puede ser considerado

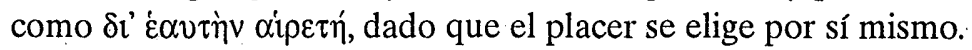

${ }^{74}$ Mitsis, P., Epicurus on Friendship, p.134-135.

75 Mirsis, P, Epicurus on Friendship, p. 130-131.

76 Mitsis, P., Epicurıs, p. 103s. y 114. Mitsis descubre en Epicuro algo semejante a lo que aparece en $S$. Mill, quien reconoce que no todas las cosas se desean o se hacen para conseguir el placer. Considera que la música o la salud pueden ser medios para alcanzar la felicidad, pero también pueden ser fines en sí mismas. Véase también MiTsis, P, Epicurus on Friendship, p. 132.141.143. y. 153. MILL, J. S., El lttilitarismo. Un sistema de lógica (=Humanidades 1054), Alianza Editorial, Madrid 1984, p. 92.

77 RIST, M. J., Epicurus, p. 133. La amistad conduce directamente al placer. Por eso Epicuro era capaz de decir, que de todos los medios que proporcionan la vida feliz, la amistad es el más importante y el más fecundo. 
Otro aspecto importante para ver el sentido altruista de la amistad reside en esto: la más importante ventaja que podemos obtener de la amistad no son bienes materiales sino algo intangible, un sentimiento de confianza ${ }^{78} \mathrm{de}$ cara al futuro; así aparece en la $S V$ 34. Esto significa que nosotros necesitamos menos la ayuda de los amigos que la confianza de que ellos nos ayudarán en el futuro cuando lo necesitemos. Este sentido se corresponde con el sentimiento de una solidaridad real no destinada a conseguir ventajas inmediatas, sino como remedio para los problemas venideros. La amistad epicúrea es una confianza recíproca, un esfuerzo por ser benevolentes con los otros. Así, el debate sobre la utilidad sería un debate espurio ${ }^{79}$. La idea de utilidad debe entenderse como beneficio mutuo que no se centra en los beneficios del momento presente, sino en el esfuerzo constante de mantener la amistad en el futuro y los beneficios recíprocos de lo que se hace en común. Una vez más se dice que la amistad es más útil por sí misma que por las ventajas precisas del momento. De ahí que una de las características de la amistad sea afrontar riesgos ( $S V 28)$. El riesgo que tenemos que pagar por la confianza en el amigo nos puede traer su sufrimiento y tristeza si el amigo tiene algún problema o está sufriendo ( $S V$ 56-57) y, si se diera el caso, estaría dispuesto a morir por él; ya que, si no es fiel al amigo, toda su vida estará agitado y torturado en su interior. Este sentimiento de amistad no se expresa llorando exteriormente, sino compartiendo los sentimientos de los amigos ( $S V$ 66) y haciendo algo para que logren salir de su situación.

Finalmente, recordemos el dicho atribuido a Epicuro (D.L. X, 120-121): "El sabio nunca traicionará a un amigo, y morirá por él". Esta afirmación es contraria al egoísmo, pues quien da su vida por otro realiza un gesto eminentemente altruista. Plutarco (Us. 546) recoge lo que dijo Epicuro: "Aunque se elige la amistad por causa del placer, él recibe las más grandes penas a causa de sus amigos" 80 . La amistad es un deseo necesario para la vida, algo imprescindible. La amistad precisa estar fundada en cierto desinterés. Como se ve, es cuestión de autosuficiencia: el sabio enfrentado a la necesidad está más dispuesto a ayudar y a dar que a recibir para sí (SV 44). Plutarco en Us. 544 recoge algo semejante: no sólo es más noble, sino también más placentero dar que recibir beneficios; es mejor dar que recibir. Una vez más nos recuerda al

78 Glad, E. C., Paul and Philodemus, p. 162. Insiste en que los amigos no se tienen para conseguir beneficios materiales, sino un bienestar espiritual, como puede ser la confianza, la intimidad, etc.

79 Fraisse, J. C., Philia, p. 316.

${ }^{80}$ LonG, A., Pleasure and social Utility, p. 304. 
Estagirita cuando habla de la generosidad: "Es más propio de la virtud hacer el bien que recibirlo" (EN IV, 1120 a 12-13).

\section{A modo de conclusión}

Concluyamos con uno de los fragmentos más admirados de Epicuro, donde se abre a este sentido más altruista de la amistad. La SV 52 dice: "La amistad recorre o danza por el mundo entero anunciándonos a todos a que nos despertemos para la felicidad". Este fragmento, como comenta Lledó, resultó tan extraño que varios traductores en lugar de amistad leyeron filosofía. Con esta noción nos acercamos al concepto epicúreo de filantropía que prescribe el amor a la humanidad entera, la amistad con todos los hombres sin distinción de razas. Lledó 81 apunta que este texto es uno de los más significativos por su belleza y por la originalidad de su proyecto ecuménico ${ }^{82}$, es decir, de solidaridad universal. Antoni Piqué 83 traduce D. L. X, 10 por "su filantropía con todos" y nos recuerda que los sentimientos filantrópicos 84

81 Lledó, E., El epicureísmo, p. 127. Comte-Sponvile, A., Pequeño tratado, p. 336-337. La filantropía se refiere a una cierta idea de humanidad, gracias a la cual todos los hombres están vinculados en nombre de una humanidad común, de una vida común; una inclinación natural a amar a los hombres, una forma de ser que lleva a la beneficencia y a la benevolencia. Epicuro, según esta interpretación, tuvo una voluntad de universalización de la amistad y se aproximaría a la filantropía y se iría acercando a la caridad. Sentir que somos hermanos ante la vida, que somos humanos, todos somos hermanos ante la muerte: la caridad sería como una fraternidad entre los mortales.

82 Tuilier, M. A., La notion, p. 322-328. Señala que este sentido ecuménico es propio de la época helenística y consecuencia de las conquistas de Alejandro que hace de los griegos y bárbaros un solo pueblo. Además ve también en esta oposición entre la $\phi \mathfrak{\imath} \lambda$ í $\alpha$ universal o ecuménica de Epicuro y la $\phi \imath \lambda i ́ \alpha \pi 0 \lambda \imath \tau \iota \kappa \eta ́$ de Aristóteles la reproducción del paso de la organización política centrada en la polis a la monarquía universal de Alejandro y el imperio romano posterior. Véase también MülLER, R.; Die Epikureische Gesellshaftstheorie, p. $128 \mathrm{~s}$.

83 Diógenes laercio, Vida de Epicuro. Libro $X$ de las Vidas de los filósofos ilustres, in., tr. y notas de Antoni Piqué Angordans, Universitat de Barcelona, Barcelona 1981.

84 TARn, W., \& Griffith G.T., Hellenistic Civilisation, Menthuen and Co Ltd, London 1974 , p. 110s. La filantropía entendida como la ayuda organizada hacia los pobres por los ricos era casi desconocida. Hablando ampliamente la conmiseración con el pobre no tenía cabida en el carácter normal de Grecia. Se podría haber esperado de los estoicos y los cínicos con su sentido de hermandad hubieran cultivado la filantropía, pero no lo hicieron. Para los estoicos la pobreza, como la esclavitud, afectaba sólo al cuerpo y, por lo tanto, era algo indiferente (RoDIS-LEWIS, G., Epicure, p. 360). Diógenes de Enoanda manifiesta, en este texto, la influencia de un universalismo difundido por los estoicos, dado que el epicureísmo no se había preocupado por las generaciones futuras. Las preocupaciones del Maestro para que los hijos de Metrodoro pudieran estudiar filosofía debería matizar al menos la última 
eran, por lo general, desconocidos en esta época ${ }^{85}$, así como la compasión por los esclavos (D. L. X, 118), la asistencia a los pobres y la atención a los enfermos.

La primera afirmación clara del cosmopolitismo epicúreo se encuentra en Diógenes de Enoanda (frg. 30): "Además el amor a la humanidad nos lleva a socorrer a los extranjeros que lleguen por aquí... Y no menos hemos hecho esto a favor de los llamados extranjeros, que en verdad no son tales. Porque, según la división parcial de la tierra, cada uno tiene una patria distinta, pero, según la extensión completa del mundo, nuestra patria, de todos, es la tierra entera y un único mundo es su morada (de todos)". Las fronteras nacionales son artificiales, hay una casa natural, el universo, que es la patria común ${ }^{86}$.

Epicuro es mensajero de una misión universalista: anunciar y desarrollar la salvación a todos los hombres, liberarles de la infelicidad humana (Us. 221). Ahora bien, se le puede objetar a Epicuro que los propios amigos no son la humanidad entera y mucho menos sus conciudadanos en general. Incluso si la filantropía en general es evidente, su ética se restringe a la esfera de aquel sentimiento hacia los amigos. De esta manera se pueden entender las palabras de la inscripción de Diógenes de Enoanda: es justo ayudar a la posteridad, a aquellas generaciones que no han nacido y además asistir a los extranjeros que están aquí. Pero parece que Epicuro se refería sólo a los miembros de su comunidad, aunque fuesen extranjeros o no nacidos allí; se limitaría únicamente a los de su grupo y, por lo tanto, no se abriría del todo al cosmopolitismo.

Los epicúreos presentan un horizonte distinto de solidaridad, más allá de la política, el que hace referencia a la amistad ( $G V$ 52): "La amistad danza

afirmación. ¿Pero hay filantropía universal en los epicúreos? El término es utilizado incidentalmente por D. L. X 10, para mostrar la preocupación de Epicuro hacia todos. Aparece también en un fragmento de Herculano pero con una benevolencia que no se dirige necesariamente a la humanidad entera.

85 Por otro lado, conforme avanza la época helenística -en tiempo del imperio romano-, la filantropía llegó a convertirse en un tópico muy socorrido-el de que el amigo es una ayuda segura en la adversidad-que se inserta en el ámbito de la $\phi 1 \lambda \alpha \nu \theta \rho \omega \pi i \alpha$ tan grata al pensamiento antiguo.

86 García gual, C., Epicuro (=Humanidades 806), Alianza editorial, Madrid 1985, p. 235. Voelke, A. J., La philosophie comme thérapie de l'âme. Etudes de philosophie hellénistique, (=vestigia 12), Editions Universitaires de Fribourg Suisse, Fribourg 1993, p. 68. Este pasaje citado presenta algunas características que pueden sorprender. La preocupación por las generaciones futuras y los extraños, la llamada a la filantropía, contrasta con el repliegue sobre sí o sobre una comunidad pequeña de amigos en la que Epicuro vivía. Aunque el texto pertenece a Diógenes de Enoanda y estos rasgos se explican por la influencia estoica o más ampliamente por el espíritu cosmopolita de la época. 
alrededor del mundo...", que permitiría a los hombres, en cuanto átomos aislados, liberarse de su insolidaridad y abrirles a un nuevo tipo de relación propia de la cosmópolis. Esa comunidad de hombres que descubren la común tarea de fraternidad es, efectivamente, un proyecto que entonces debió parecer utópico, pero que después de veinte siglos se confirma como la única posibilidad de pervivencia y de sentido 87 .

De todos modos, a pesar de esta evolución de la amistad y de los diversos sentidos que hemos visto: de la amistad interesada a la amistad altruista, tenemos que concluir que todavía hay distancia para que la amistad se traduzca en $\dot{\alpha} \gamma \alpha \dot{\alpha} \pi \eta$ cristiano. La caridad cristiana va unida a la compasión que supone sufrir con el extraño, que es un prójimo al que se ama y se le presta una caridad fraternal. Ahora bien, como dice Tuilier, la $\phi i \lambda i \alpha$ epicúrea es el

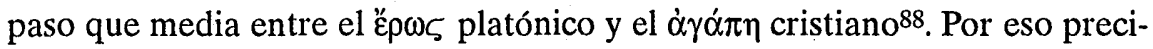
samente, para que pueda darse esa transición es necesario que se pueda hablar de una amistad altruista en Epicuro, en la que no se busca el propio bien o que se llega amar al otro por sí mismo, independientemente de las ventajas que puedan derivarse de esa relación. La diferencia mayor que existe entre el ágape y la amistad, es que el ágape no se dirige exclusivamente a los amigos, sino a todo hombre; amar al prójimo es muy distinto de amar a los amigos; pero en alguna sentencia epicúrea, tal vez por influencia estoica o del cosmopolitismo helenista, se puede otear esta llamada a la amistad universal, por lo que no es difícil que más tarde evolucionara a una fraternidad universal ${ }^{89}$.

Esto último se entiende bien relacionado con los tres tipos de amor o tres grados de amor de los que habla Comte-Sponville: el deseo y carencia

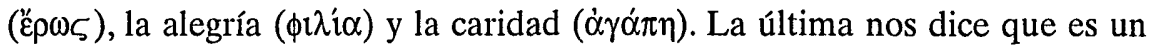
halo de dulzura, de compasión y de justicia. La auténtica caridad es el amor sin retorno, sin esperar nada a cambio. Tal vez nosotros no consigamos vivir

87 Lledó, E., El epicureísmo, p. 128. "Un proyecto utópico no porque estuviese fuera de la posibilidad del espacio humano, sino porque es ardua la tarea de "realizarlo". Pero que no es utópico lo demuestra el lenguaje que hemos tenido que aceptar: el de los derechos humanos, el de la esperanza, el de la concordia, porque constituyen el ideal que, aunque sólo sea por el hecho de ser expresado, nos libera de la desesperación y del pesimismo".

88 TUILIER, M. A., La notion, p. 329.

89 Por supuesto, en Epicuro no se puede hablar de un amor al prójimo (a cualquier hombre), pero comparado con Aristóteles que dice que hay que tratar al amigo como a uno mismo, con un sentido restrictivo de amistad. De Epicuro se puede afirmar que en algunas de sus sentencias se abre a una amistad universalista que, evolucionando, podría desembocar en un amor o fraternidad universal con la llegada del cristianismo. 
este amor totalmente desinteresado. ¿Podemos vivir un amor así? ¿Podemos aproximarnos a él? Quizás la amistad sea el único amor generoso del que somos capaces los humanos y esto es posiblemente lo que los epicúreos habrían objetado seguramente a san Pablo y a los primeros cristianos ${ }^{00}$. La caridad no necesita del sufrimiento del otro para amarlo (por lo que aventajaría a la compasión). La caridad sería como la compasión liberada del sufrimiento o como la amistad liberada del ego. En su concepción de la amistad desinteresada, los epicúreos se abren al altruismo, por lo que habrían, en cierto modo, anticipado o serían al menos un eslabón que conduciría al amor gratuito o ágape.

Javier ANTOLÍN SÁNCHEZ

Estudio Teológico Agustiniano

Valladolid

90 Comte-Sponville, A., Pequeño tratado, p. 347-348. 